\title{
Economic figures of plum production at national level of Hungary
}

\author{
Felföldi, J., Ványi, N., Apáti, F., Nyéki, J., Szabó, Z. \& Gonda, I. \\ University of Debrecen Centre for Agricultural and Applied Economic Sciences \\ H-4032 Debrecen, Böszörményi út 138., Hungary
}

\begin{abstract}
Summary: In Hungary, natural conditions are optimal for growing plums. In spite of that, plum production was not a successful business in the past years. The reasons of it are, first of all, the utter fluctuation of yields and of the producer's prices, increment of direct costs of production, dwindling incomes and uncertainties on the market. Serious problems are caused by the high rate of aged plantations, which are not counterbalanced by new plantings. Decisive is the "loose" ranging of the branch by the Union regarding plum production, which is expected for the sake of enlarging production and markets. Our aims are to analyse the management of the eight-year-long period, 2002-2009, and the fate of components of husbandry. The results presented are means of an utterly heterogeneous population of enterprises, being hardly suitable to make actual decisions, but they may enlighten upon challenges and recognise tendencies within the branch.
\end{abstract}

Key words: plum, value of production, costs of production, gross margin

\section{Introduction}

It is generally maintained that plum is a fruit with modest requirements regarding nursing, and the all the same, plums are found everywhere in orchards or even without active cultivation. The area assigned to plums occupies $9 \%$ of the Hungarian fruit growing. Plums are highly adapted to the local ecological conditions, in spite of that, plum production was not a lucrative business in Hungary. Yearly plum consumption per capita is $1.5-2 \mathrm{~kg}$, which grows slightly albeit its recognised healthy sanitarian effects. The volume of product is at present about $50000 \mathrm{t} / \mathrm{year}$, compared with the years of the 1990-es, it dwindled to less than its half. One has to admit that the plantations are not up to date any more, nor competitive, obsolete, cannot be irrigate. New plantings are scarce. The policies of the last 20 years did not stimulate plum growing by subsidies, and it still did not promote by temporary arrangements for the care of plantations.

Plums are grown equally for the market of fresh consumption as well as for industrial processing. Products are offered in the market as marmalade, compote, brandy, refrigerated and desiccated fruits. The ware for fresh consumption should be the most favourite product, but it would require an up to date equipment and adequate infrastructure for storing and manipulation. The sale of fresh consumption as well as processed products produced stimulating positive results during the last years.

There below we will publish the results of the study the economic relations of the period: 2002-2009 and analysis of the main components.

\section{Materials and methods}

Relevant data are found in the database of the Research Institute for Rural Economics (AKI) being accumulated and ready for being processed. The period between 2009 and 2002 was consulted for being analysed regarding values, costs and incomes. Not only basic data but also derivates are processed to find the essential parameters of managements. As the results are means of an extremely heterogeneous population, they are not suitable to apply them to answer immediate questions of a particular management. They reveal general tendencies of the economic milieu and suggest valid regularities for countrywide decisions.

\section{Results}

Figure 1 shows that in Hungary 245 000-390 $000 \mathrm{Ft} / \mathrm{ha}$ was the expected value of plum production during the period 2002-2009. These data include the state and EU subsidies. In 2002, the value was $267000 \mathrm{Ft} / \mathrm{ha}$, and rose in 2003 by some thousand Fts. In 2004, however, the increment was more substantial, but in 2008 it reached $392000 \mathrm{Ft} / \mathrm{ha}$. Plum growing plantations received $7000-81000 \mathrm{Ft} / \mathrm{ha}$ subsidies between 2002-2009. In 2004, the year of joining Hungary to the European Union, the subsidies increased grandiosely, as instead of $7000 \mathrm{Ft} / \mathrm{ha}$, growers received 26000 , and in 2009 already $26000 \mathrm{Ft} / \mathrm{ha}$. Figure 1 proves that the values of byproducts was negligible with one exception in 2005, when nearly $47000 \mathrm{Ft} / \mathrm{ha}$ was the income of the branch. 


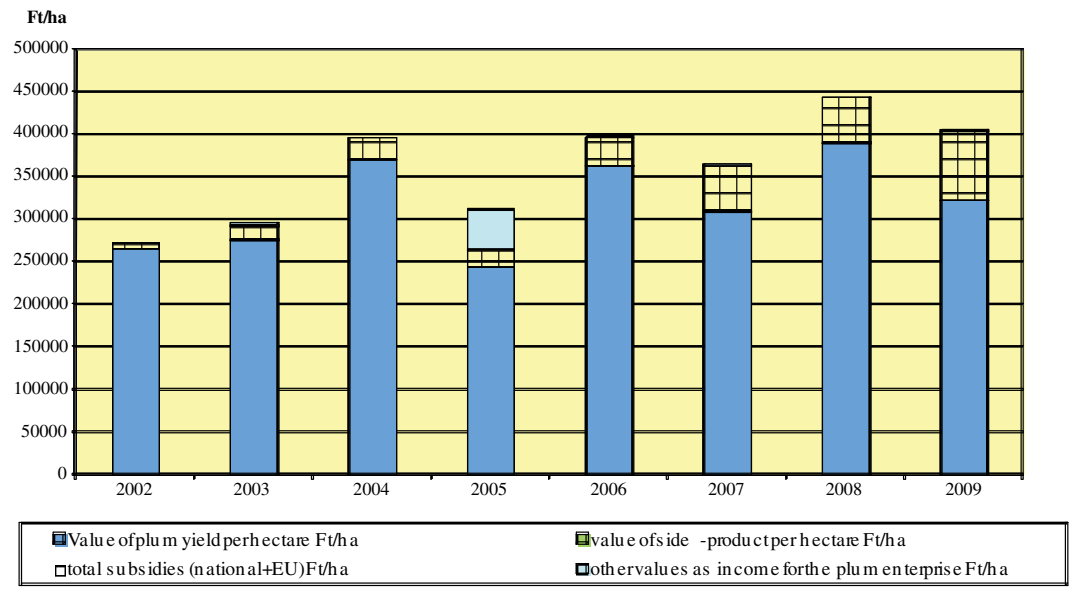

Figure 1. Values produced by plums growers in farms relevant on the Hungarian markets Source: AKI and original calculations

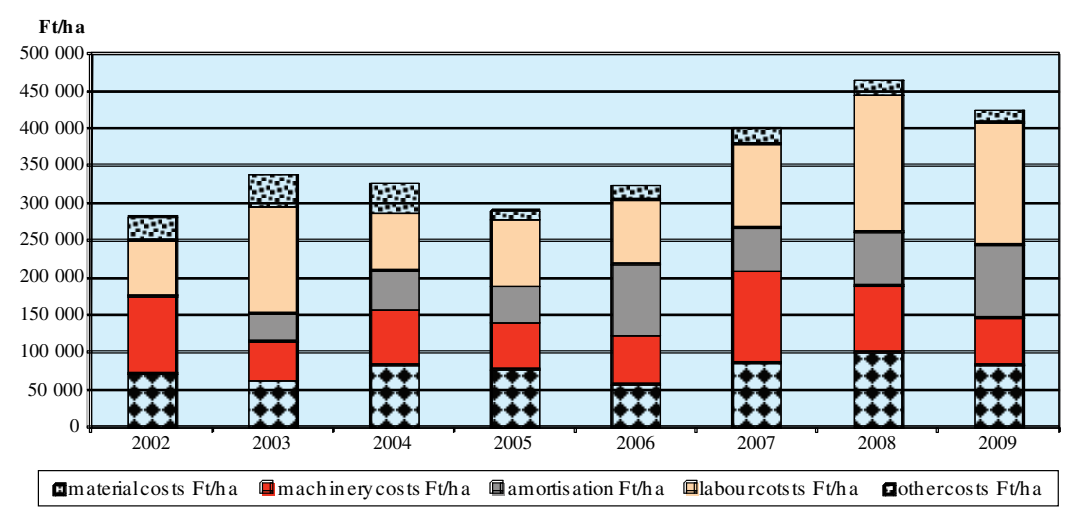

Figure 2. Direct costs of plum production in Hungary in farms relevant for the market

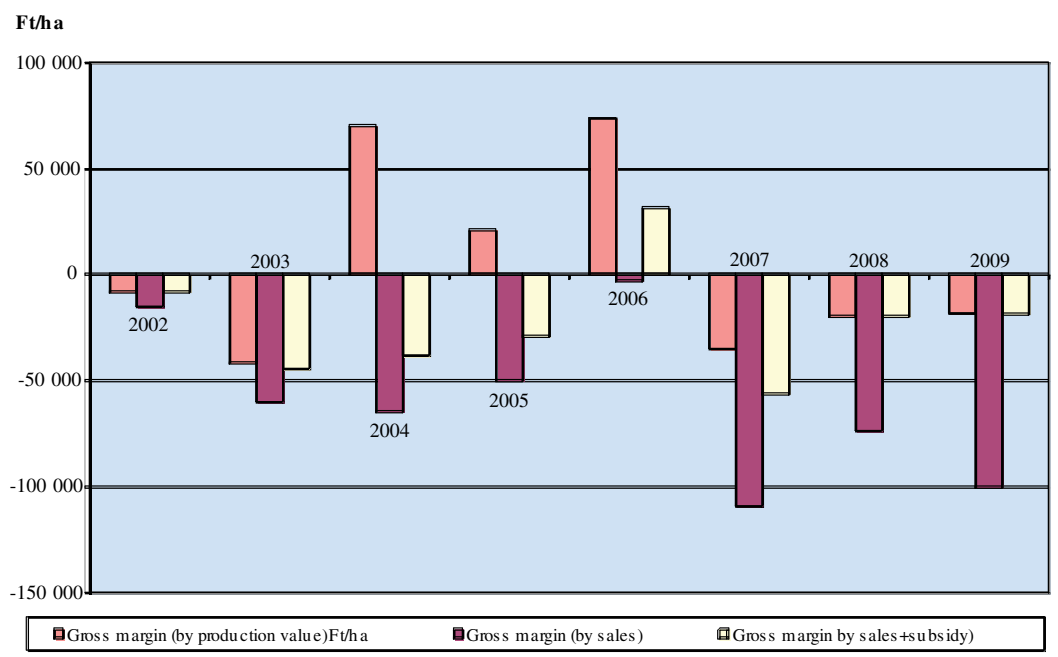

Figure 3. The changes of the gross margin of plum production

If the production would concentrate, consequently, upon the main product with a purposeful technology, increment of yields as well as of producer's prices is expected.

Direct costs of plum production are presented in Figure 2. Material costs, costs paid for machines, amortisation, labour and other costs are together giving the direct costs. In 2002, $25 \%$ of direct costs were the material costs, which diminished to $18 \%$ in 2009. Material costs fluctuated continuously and culminated in
2008 with $10100 \mathrm{Ft} / \mathrm{ha}$ being the lowest in 2006. Most important item of material costs is spent for phytosanitary products, i.e. 47000 $80000 \mathrm{Ft} / \mathrm{ha}$. Also expenses for chemical fertilisers fluctuated: $2000-20000 \mathrm{Ft} / \mathrm{ha}$. In 2008, costs of materials were as follows: phytosanitary products: $80000 \mathrm{Ft} / \mathrm{ha}$, fertilisers much less: $18644 \mathrm{Ft} / \mathrm{ha}$, sowing seed and nursery products $2000 \mathrm{Ft} / \mathrm{ha}$.

Costs spent for machines was 104000 $\mathrm{Ft} / \mathrm{ha}$ in 2002, and diminished to its half in 2003. During the subsequent years it fluctuated continuously, In 2007, 122 000, in 2002, $104000 \mathrm{Ft} / \mathrm{ha}$ were registered, out of the latter $83000 \mathrm{Ft} / \mathrm{ha}$ was paid for hired mechanical services. High sum of $52000 \mathrm{Ft} / \mathrm{ha}$ was calculated for works done by machines owned by the growers. The rate of machines owned by the farmers themselves grew gradually. It is a sign of the growers' increasing wealth or of a better exploitation of machines.

The specific amortisation costs changes in the same sense, as being less than $2000 \mathrm{Ft} / \mathrm{ha}$ in 2000, and increased already in 2003, and was $97000 \mathrm{Ft} / \mathrm{ha}$ in 2009.

Labour costs were $72000 \mathrm{Ft} / \mathrm{ha}$ in 2002, and $164000 \mathrm{Ft} / \mathrm{ha}$ in 2009. Wages and the accessory costs grew yearly by $14 \%$ (wages) and by $10 \%$ (accessories). The highest values appeared in 2008, $144000 \mathrm{Ft} / \mathrm{ha}$ for wages and $40000 \mathrm{Ft} / \mathrm{ha}$ accessories.

Other costs decreased from $31000 \mathrm{Ft} / \mathrm{ha}$ to $15000 \mathrm{Ft} / \mathrm{ha}$.

Direct costs increased during 2002-2009 by $200000 \mathrm{Ft} / \mathrm{ha}$, which is rather high related to the modest increment of yields.

General costs fluctuated between 24000 and $58000 \mathrm{Ft} / \mathrm{ha}$ during the observed period.

In Figure 3, we showed the coverage of plum production during the period 2002-2009. Three categories of values are explored the values of production, the price income plus subsidy and the incomes alone. We subtracted the direct costs of production from all the three sums to facilitate an easier comparison. All three methods of calculating coverage furnished different results. All three methods of calculating coverage furnished different results. The calculation with the values of production the coverage ended with positive results only in the years 2004-2006, the rest of years showed deficits for the plum growing branch (Figure 3 ).

The yearly fluctuation of income by sales paralleled with the direct costs. The gradual increment of the latter was coupled with diminished fluctuation, but it was higher than the income by sales. Together with the general costs, the result was a negative net income during the interval 2002-2009. Outstanding deficits are registered in 2006 with - $110000 \mathrm{Ft} / \mathrm{ha}$ (Figure 4). 


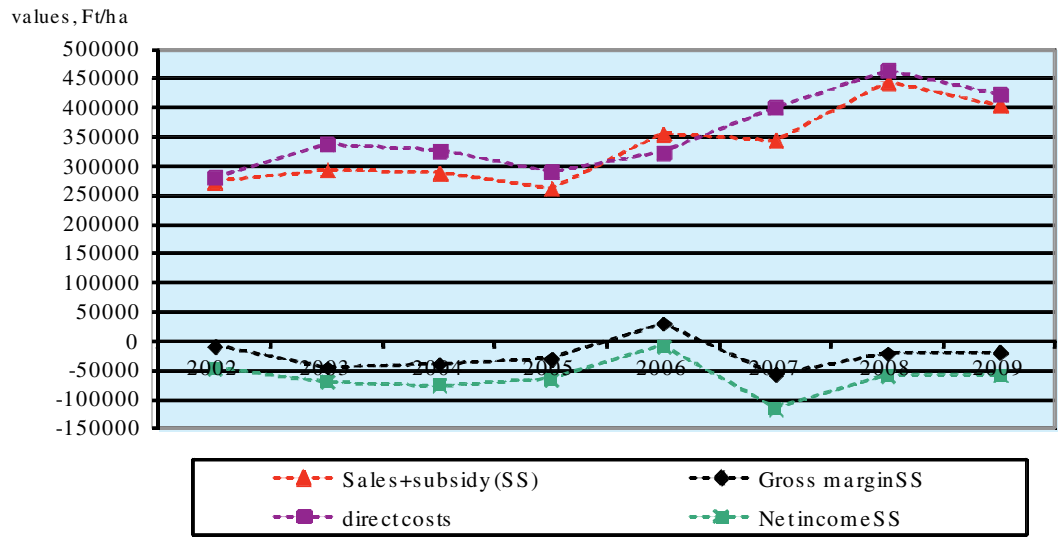

Figure 4. Sales, costs and incomes during the period 2002-2009 in plum production Source: AKI and original calculations

Remark: Gross marginSS = Sales+Subsidies (SS) minus direct costs of enterprise production; Net IncomeSS $=$ Gross marginSS minus indirect costs for the enterprise

The net income cannot become positive in spite of the subsidies except in the year 2006.

\section{Conclusions}

Mean plum yields in Hungary were $4-10$ t/ha during the period studied. The fluctuation of yields and of producer' prices make the market incalculable. After joining of
Hungary to the EU, in 2004, more subsidies have been given to the plum production branch. During the eight-year-period (20022009) hectic fluctuations were registered in production costs, increasing labour costs and amortisation nearly doubled, whereas costs spent for mechanical services diminished markedly. The sum of coverage calculated from the sales' income could not achieve positive incomes at no time. Summarising the results of the period we may state that plum production has been a losing branch of the Hungarian agriculture.

\section{Acknowledgement:}

This paper is supported by the *János Bolyai Research Scholarship of the Hungarian Academy of Sciences and the NFÜ-TECH-08-A3/2-2008-0373 grant

\section{References}

Annual Reports of the Database of tested enterprises Research Institute of Rural Economics (AKI) Budapest 2003-2009. 